\title{
Mild microwave ablation combined with HSP90 and TGF- $\beta 1$ inhibitors enhances the therapeutic effect on osteosarcoma
}

\author{
LINGLING CHEN $^{1-4^{*}}$, MING WANG $^{1-4^{*}}$, ZEFENG LIN $^{2-4}$, MENGYU YAO $^{5}$, WANSHUN WANG $^{2}$, \\ SHI CHENG ${ }^{1,5}$, BINGLIN LI ${ }^{2}$, YU ZHANG ${ }^{5}$ and QINGSHUI YIN ${ }^{1-4}$ \\ ${ }^{1}$ The Graduate School of Southern Medical University, Guangzhou, Guangdong $510515 ;{ }^{2}$ Guangdong Key Laboratories of \\ Orthopedic Technology and Implant Materials; ${ }^{3}$ Key Laboratories of Trauma and Tissue Repair of Tropical Area of PLA; \\ ${ }^{4}$ Department of Orthopedics, General Hospital of Southern Theater Command of PLA, Guangzhou, \\ Guangdong 510010; ${ }^{5}$ Department of Orthopaedics, Guangdong Provincial People's Hospital, \\ Guangzhou, Guangdong 510080, P.R. China
}

Received June 4, 2019; Accepted April 8, 2020

DOI: $10.3892 / \mathrm{mmr} .2020 .11173$

\begin{abstract}
Osteosarcoma is the most common malignant bone tumour and the second leading cause of cancer-related death in children and adolescents. Microwave ablation has an excellent therapeutic effect on bone tumours by instantaneously increasing the temperature in the tumour; however, there is a risk of damaging the surrounding healthy tissues by exposure to a high temperature when the treatment power is too large. In the present study, two anti-tumour reagents, a heat shock protein 90 (HSP90) inhibitor (PF-04929113) and a transforming growth factor- $\beta 1$ (TGF- $\beta 1$ ) inhibitor (SB-525334) were employed to enhance the therapeutic effect of mild-power microwave ablation. It was revealed that microwaving to $48^{\circ} \mathrm{C}$ combined with HSP90 and TGF- $\beta 1$ inhibitors significantly increased the apoptotic rate of VX2 cells. The same results were observed during in vivo experiments using New Zealand rabbits to model osteosarcoma. In addition, the results indicated that the expression of cytochrome $c$, caspase-3 and caspase- 9 were upregulated in response to the treatment, which indicated that the mitochondrial apoptotic signalling pathway had been activated. These findings may provide a novel strategy for the development of microwave ablation in
\end{abstract}

Correspondence to: Professor Qingshui Yin, The Graduate School of Southern Medical University, 1023 Shatai South Road, Baiyun, Guangzhou, Guangdong 510515, P.R. China

E-mail: gzgk_yqs@126.com

Professor Yu Zhang, Department of Orthopaedics, Guangdong Provincial People's Hospital, 106 Zhongshan Second Road, Yuexiu, Guangzhou, Guangdong 510080, P.R. China

E-mail: luck_2001@126.com

${ }^{*}$ Contributed equally

Key words: osteosarcoma, microwave, transforming growth factor- $\beta 1$, heat shock protein 90 , inhibitor osteosarcoma treatment, which could effectively kill tumour cells without damaging the surrounding normal tissues.

\section{Introduction}

Osteosarcoma is the most common malignant bone tumour in children and adolescents (1). Currently, the main treatment of osteosarcoma is surgical resection combined with neoadjuvant chemotherapy (2), but the long-term survival rate of primary osteosarcoma is still only $\sim 67 \%$ (3). In recent years, microwave ablation has been successfully applied to the clinical treatment of bone tumours (3). To completely eliminate the tumour, microwave ablation currently requires ablation applied to the tumour safety boundary when treating para-articular tumours (4). However, this procedure has a risk of damaging the surrounding normal tissue when the temperature induced by microwave ablation is too high (5). Therefore, exploring a method that can kill tumour cells and reduce the temperature of the microwave ablation to protect surrounding normal tissues is of great importance for the clinical application of microwave ablation in osteosarcoma.

Tumours synthesize heat shock protein 90 (HSP90) in response to microwave stimulation (6). High expression of HSP90 increases the tolerance of tumour cells to heat and inhibits apoptotic signalling pathways (7). Furthermore, HSP90 is more abundant in tumour cells than in normal cells (8); it can inhibit the apoptosis of tumour cells by participating in various protective signalling pathways, including inhibiting the mitochondrial release of cytochrome $c$ (cyto $c$ ), inhibiting the formation of apoptotic bodies, further enhancing the tolerance of tumour cells to heat and inhibiting tumour necrosis (9). Previous studies have revealed that HSP90 inhibitors are novel and effective anticancer drugs $(10,11)$. Therefore, suppressing the expression of HSP90 in tumours under microwave ablation has the potential to enhance the therapeutic effect of microwave treatment.

Another key signalling molecule in tumour cells is transforming growth factor- $\beta 1$ (TGF- $\beta 1$ ), which can affect the growth, differentiation, metastasis and apoptosis of tumour cells (12). Animal experiments have demonstrated that TGF- $\beta 1$ 
is an effective target for tumour therapy $(13,14)$. Previous studies have reported that small inhibitors of TGF- $\beta 1$ can block SMAD phosphorylation and nuclear translocation, as well as inhibiting tumour morphological changes, cell proliferation, migration and angiogenesis $(15,16)$. To reinforce the therapeutic effect of microwave ablation, TGF- $\beta 1$ inhibitors can be combined with it in the treatment of osteosarcoma (17). It has been reported that both HSP90 and TGF- $\beta 1$ can bind to the same receptor to have synergistic effects on tumour adhesion, migration and other functions (17). In addition, HSP90 inhibitors can suppress TGF- $\beta 1$ signalling at the receptor level (17) (Fig. 1).

In the present study, microwave ablation was combined with HSP90 and TGF- $\beta 1$ inhibitors to treat osteosarcoma (Fig. 2). To the best of our knowledge, this is a rare method of applying microwave ablation in the treatment of tumours. Based on previous findings concerning cell tolerance of hyperthermia (18), four microwave ablation temperatures $(37,41,48$ and $60^{\circ} \mathrm{C}$ ) were set in this study. It was discovered that the apoptotic rate of VX2 cells was significantly increased after microwaving at $48^{\circ} \mathrm{C}$ combined with TGF- $\beta 1$ and HSP90 inhibitors. The in vivo experiments also showed the same results. In addition, it was demonstrated that the expression of cytokines in the apoptotic signalling pathway were increased. Collectively, these findings may provide a mild microwave ablation method that can kill tumour cells while avoiding damage to the surrounding normal tissue.

\section{Materials and methods}

Cell culture. The rabbit squamous cell carcinoma VX2 cells (American Type Culture Collection) and the rabbit bone marrow mesenchymal stem cells (R-BMSCs; iCell Bioscience, Inc., cat. no. s018.) were cultured in DMEM (Gibco; Thermo Fisher Scientific, Inc.), 10\% FBS (Gibco; Thermo Fisher Scientific, Inc.) and $1 \%$ penicillin-streptomycin solution. The cells were cultured in an incubator at $37^{\circ} \mathrm{C}$ and $5 \% \mathrm{CO}_{2}$. When the cells occupied $90-95 \%$ of the of the bottom of the culture flask, they were digested and prepared in suspension with a density of $1 \times 10^{4}$ cells.

After all cells were adhered to the plate for $20 \mathrm{~h}$, fresh culture medium was added with one of the following conditions: $37 \mathrm{nM}$ HSP90 inhibitor (PF-04929113; p) alone; 14.3 nM TGF- $\beta 1$ inhibitor (SB-525334; s) alone; or both $37 \mathrm{nM}$ PF-04929113 and $14.3 \mathrm{nM}$ SB-525334 (p+s). The inhibitors were purchased from Gibco; Thermo Fisher Scientific, Inc. Culture medium with no inhibitors was regarded as the control group.

Temperature rise curve. In each well of 48-well culture plates, $500 \mu 1$ DMEM was added, after which a microwave needle fixed with a temperature measuring probe was inserted into the well; the temperature measuring probe was the same type of microwave temperature measuring probe used in the clinical treatment of bone tumours. The microwave therapy device was adjusted to $15 \mathrm{~W}$ under physiotherapy mode, and the starting microwave temperature of each well was $37^{\circ} \mathrm{C}$. The microwave time was set at 15, 20, 25, 30, 40, 50 and $60 \mathrm{sec}$. The microwave treatment was repeated three times for each treatment time, the temperature of the DMEM was recorded, and the time-temperature curve was plotted.
MTT assay. The VX 2 cell suspension density was $7 \times 10^{4}$ cells $/ \mathrm{ml}$ and $500 \mu \mathrm{l}$ suspension was added to each well of a 48 -well plate. After incubation for $20 \mathrm{~h}$ in a $37^{\circ} \mathrm{C}$ constant temperature incubator, fresh culture medium was added with the inhibitors (as aforementioned). After co-culture with inhibitors for $4 \mathrm{~h}$, each group was heated by microwave to $37,41,48$ and $60^{\circ} \mathrm{C}$. The R-BMSCs were used to repeat the aforementioned procedure and were microwaved to $48^{\circ} \mathrm{C}$. After $4 \mathrm{~h}$, the cells were incubated with $5 \mathrm{mg} / \mathrm{ml} \mathrm{MTT}$ solution in a $37^{\circ} \mathrm{C}$ incubator for $4 \mathrm{~h}$, and the crystal violet was dissolved with DMSO solution. The optical density values at $490 \mathrm{~nm}$ were measured using a microplate reader. The cell survival rates were calculated by reference to the control group at $37^{\circ} \mathrm{C}$. Each experimental condition was repeated three times.

Calcein/PI staining. After the cells were cultured with the inhibitors and heated, the supernatant was discarded, and $200 \mu \mathrm{l}$ calcein/PI (Gibco; Thermo Fisher Scientific, Inc.) solution was added to each well. After $30 \mathrm{~min}$ incubation at $37^{\circ} \mathrm{C}$, the cell viability was observed under a fluorescence inverted microscope (Olympus Corporation) and images (magnification, x200) were captured.

Flow cytometry. Apoptosis of cells was tested in the following groups: Microwave alone (M); microwave $+37 \mathrm{nM}$ PF-04929113 (M+p); microwave + 14.3 nM SB-525334 $(\mathrm{M}+\mathrm{s})$; and microwave $+37 \mathrm{nM}$ PF-04929113 + $14.3 \mathrm{nM}$ SB-525334 $(\mathrm{M}+\mathrm{p}+\mathrm{s})$ groups. Following addition of the inhibitors, the groups received microwave ablation with a power of $15 \mathrm{~W}$ and a duration time of $40 \mathrm{sec}$. Subsequently, the cells were collected, washed twice with cold PBS, stained with Annexin V-FITC and PI (BD Biosciences, Inc.) for $30 \mathrm{~min}$ at $4^{\circ} \mathrm{C}$ in the binding buffer and analysed by flow cytometry (FACSCalibur flow cytometer; BD Biosciences) and FlowJo software 10.6 (FlowJo LLC).

Cellular immunofluorescence assay. The cells in the control, $\mathrm{M}, \mathrm{M}+\mathrm{p}, \mathrm{M}+\mathrm{s}$ and $\mathrm{M}+\mathrm{p}+\mathrm{s}$ groups were fixed with $4 \%$ paraformaldehyde for $15 \mathrm{~min}$ at room temperature. After washing twice with PBS, cells were permeabilized using a $0.2 \%$ Triton $\mathrm{X}-100$ solution and subsequently blocked with $3 \%$ BSA (neoFroxx $\mathrm{GmbH}$ ) for $30 \mathrm{~min}$ at room temperature. Next, the cells were incubated for $8 \mathrm{~h}$ at $4^{\circ} \mathrm{C}$ with primary antibodies against TGF- $\beta 1$ (cat. no. sc-130348, 1:1,000), SMAD4 (cat. no. sc-73040, 1:1,500), HSP90 (cat. no. sc-101494, 1:1,000), caspase-3 (cat. no. sc-56046, 1:1,500), caspase-9 (cat. no. sc-56076, 1:1,000) and cyto $c$ (cat. no. sc-75806, 1:1,000 all from Santa Cruz Biotechnology, Inc.), washed with PBS and incubated for $1 \mathrm{~h}$ at $37^{\circ} \mathrm{C}$ with Alexa Fluor ${ }^{\circledR} 488$ goat anti-rabbit IgG secondary antibody (1:1,000; cat. no. A32731, Invitrogen, Thermo Fisher Scientific, Inc.). Nuclei were stained using DAPI for $5 \mathrm{~min}$ at $37^{\circ} \mathrm{C}$. Images (magnification, $\mathrm{x} 400$ ) were acquired using a confocal laser-scanning microscope (Olympus Corporation).

Western blotting analysis. The cells in the control, $\mathrm{M}, \mathrm{M}+\mathrm{p}$, $\mathrm{M}+\mathrm{s}$ and $\mathrm{M}+\mathrm{p}+\mathrm{s}$ groups were lysed on ice with RIPA (Thermo Scientific, Inc.) for $30 \mathrm{~min}$ to extract the total protein. Protein concentration was assessed using a BCA protein assay kit. Protein $(60 \mu \mathrm{g})$ from each sample were separated by 


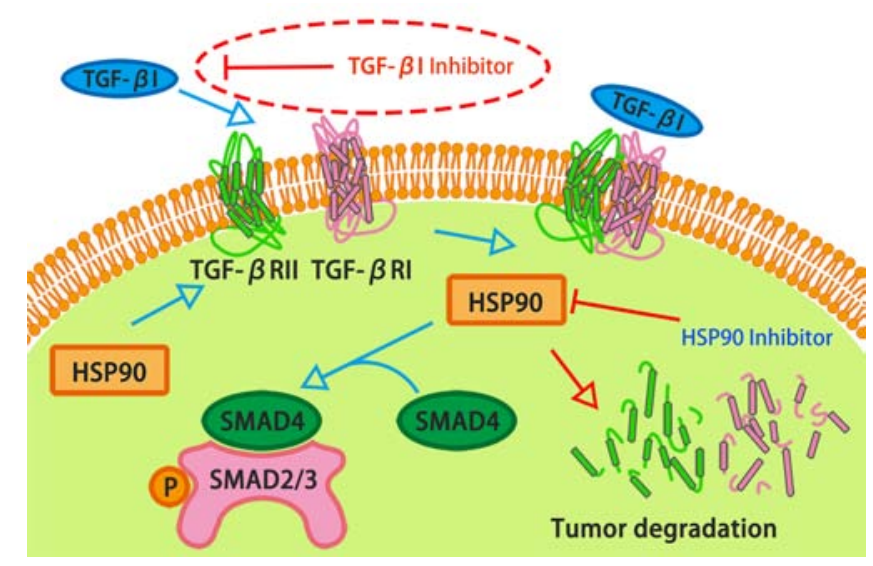

Figure 1. Schematic diagram of HSP90 inhibitor combined with TGF- $\beta 1$ inhibitor promoting the tumour apoptosis-signalling pathway. HSP90, heat shock protein 90 ; TGF- $\beta 1$, transforming growth factor- $\beta 1$; SMAD, SMAD family member.

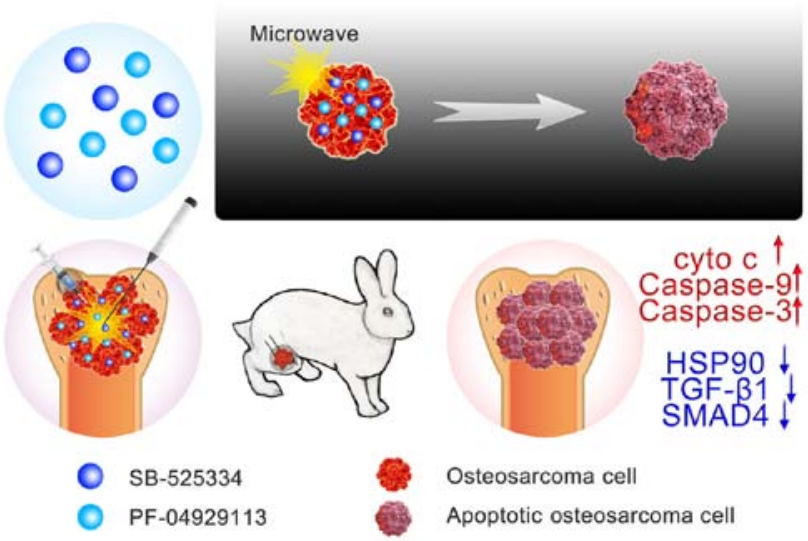

Figure 2. Schematic illustration of mild microwave ablation combined with HSP90 and TGF- $\beta 1$ inhibitors. HSP90, heat shock protein 90; TGF- $\beta 1$, transforming growth factor- $\beta 1$; SMAD4, SMAD family member 4 ; cyto $c$, cytochrome $c$.

SDS-PAGE using a $10 \%$ acrylamide gel and transferred to PVDF transfer membranes (EMD Millipore). Membranes were blocked for $1 \mathrm{~h}$ at room temperature with $5 \%$ non-fat dried milk in TBS containing $0.05 \%$ Tween-20 (TBST) buffer and incubated overnight at $4{ }^{\circ} \mathrm{C}$ with primary antibodies against TGF- $\beta 1$ (cat. no. sc-130348, 1:2,000), SMAD4 (cat. no. sc-73040, 1:2,000), HSP90 (cat. no. sc-101494, 1:1,000), caspase-3 (cat. no. sc-56046, 1:1,100), caspase-9 (cat. no. sc-56076, 1:1,000) and cyto $c$ (cat. no. sc-75806, 1:1,000 all from Santa Cruz Biotechnology, Inc.). After washing three times for $5 \mathrm{~min}$ in TBST buffer, the membranes were incubated with the HRP-Goat Anti-Mouse IgG (Jackson ImmunoResearch Laboratories, Inc., cat. no. 115-035-003) for $30 \mathrm{~min}$ at room temperature. Protein bands were detected with Immobilon Western Chemiluminescent HRP Substrate (EMD Millipore) and analysed with the Bio-Image Analysis system: BOX F3 (Syngene) and ImageJ v1.8.0 (National Institutes of Health).

Establishment of an osteosarcoma model. All animal studies were approved by the Institutional Animal Care and Use
Committee of Guangzhou General Hospital of Guangzhou Military Command of PLA (Guangzhou, China). Rabbits $(n=31)$ were housed individually in stainless steel cages and maintained with free access to both food and water. The rabbits were housed in an environmentally controlled breeding room, with at least 10 air changes per hour. The animal feeding room was maintained between $18-26^{\circ} \mathrm{C}$ and $30-70 \%$ relative humidity. Under the control of a timer, a12-h light/dark cycle was maintained. VX2 cells were suspended at a concentration of $1 \times 10^{7}$ cells $/ \mathrm{ml}$. The tibial tuberosity of a New Zealand rabbit was exposed, $1 \mathrm{ml}$ bone marrow was extracted and then $1 \mathrm{ml}$ VX2 cell suspension was injected into the bone marrow cavity. After formation of the tumours, the tumour tissue was removed and cut into tumour tissue blocks (volume, $0.5 \mathrm{~mm}^{3}$ ). Subsequently, the other $301.5 \mathrm{~kg}$ healthy male New Zealand rabbits were anaesthetized by injecting $30 \mathrm{mg} / \mathrm{kg} 3 \%$ pentobarbital into the ear vein. The tumour tissue blocks were transplanted into a femoral condyles bone defect ( $5 \mathrm{~mm}$ in diameter and $5 \mathrm{~mm}$ in depth) and the defect was closed with bone wax. The tumour model rabbits were obtained 1 week after implantation.

In vivo treatment. The tumour model rabbits were anaesthetized with $30 \mathrm{mg} / \mathrm{kg} \mathrm{3 \%}$ pentobarbital in the ear vein. Tumor volume was measured by Vernier calipers prior to surgery. The rabbits then received injections of the inhibitors followed by microwave treatment. The groups were: Control (no drugs or microwave treatment); $\mathrm{M}$ (microwave only); $\mathrm{M}+\mathrm{p}$ (microwave plus PF-04929113, $55.5 \mathrm{nM}, 100 \mu \mathrm{l}$ ); M+s (microwave plus SB-525334, $21.45 \mathrm{nM}, 100 \mu \mathrm{l}$ ); and $\mathrm{M}+\mathrm{p}+\mathrm{s}$ (microwave plus the two inhibitors). Microwave ablation was conducted at a power of $15 \mathrm{~W}$ with a duration time of $40 \mathrm{sec}$ under physiotherapy mode. The body weight and tumour sizes of the rabbits were measured every other day for a period of 21 days. Tumour size was measured with calipers and volume was calculated as follows: $\mathrm{V}=\mathrm{ab}^{2} / 2$; where $\mathrm{V}\left(\mathrm{cm}^{3}\right)$ is tumour volume, and a $(\mathrm{cm})$ and $\mathrm{b}(\mathrm{cm})$ are tumour length and width, respectively. After all experimental data and samples were collected, the rabbits were euthanized by intravenous injection of $100 \mathrm{mg} / \mathrm{kg}$ pentobarbital sodium (19), the tumor tissues were $<10 \%$ the weight of the rabbits at the time of sacrifice.

Haematoxylin and eosin $(H \& E)$ staining. The tumour tissues were fixed in $4 \%$ paraformaldehyde for $>30 \mathrm{~min}$ at room temperature, embedded in paraffin and cut into $5-\mu \mathrm{m}$ slices. The histological morphology of the tumours was acquired with $\mathrm{H} \& \mathrm{E}$ staining for $15 \mathrm{~min}$ at room temperature. All samples were observed under a fluorescence microscope (magnification, x400; BX51; Olympus Corporation).

Immunohistochemical staining. After deparaffinization and rehydration, the 5- $\mu \mathrm{m}$ tumor sections were treated with $3 \%$ hydrogen peroxide for $15 \mathrm{~min}$ at room temperature and blocked with 10\% goat serum (Sigma-Aldrich; Merck KGaA) for 20 min at room temperature. Subsequently, they were incubated with primary antibodies in PBS for $8 \mathrm{~h}$ at $4^{\circ} \mathrm{C}$. After washing, secondary antibodies were added and incubated for $20 \mathrm{~min}$ at room temperature. The antibodies used were identical to the antibodies used in the cellular immunofluorescence assay. Subsequently, HRP-conjugated streptavidin and 3,3'-diaminobenzidine solution were added to the slides and developed for 

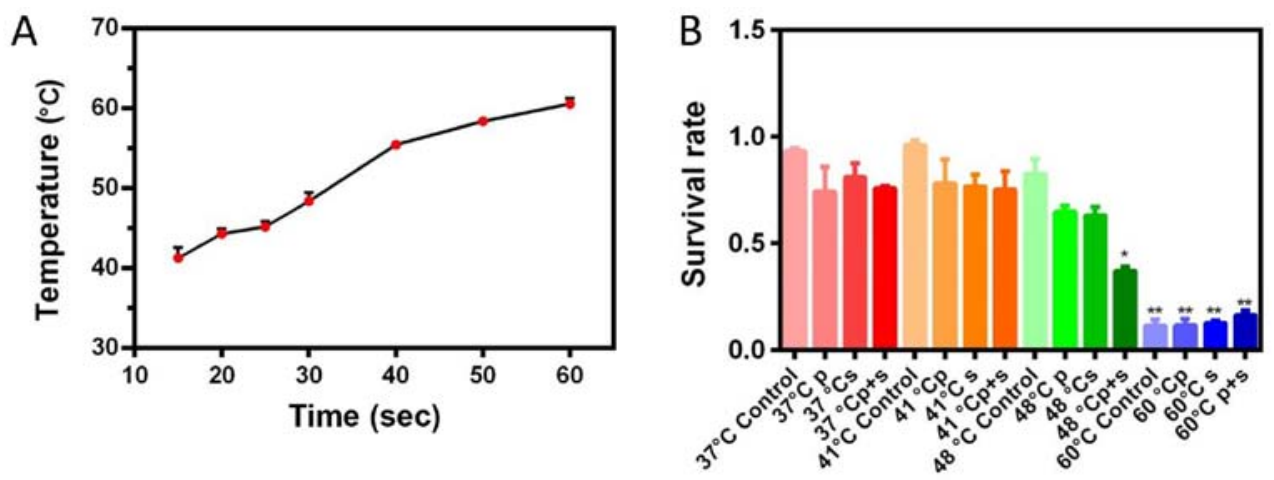

C

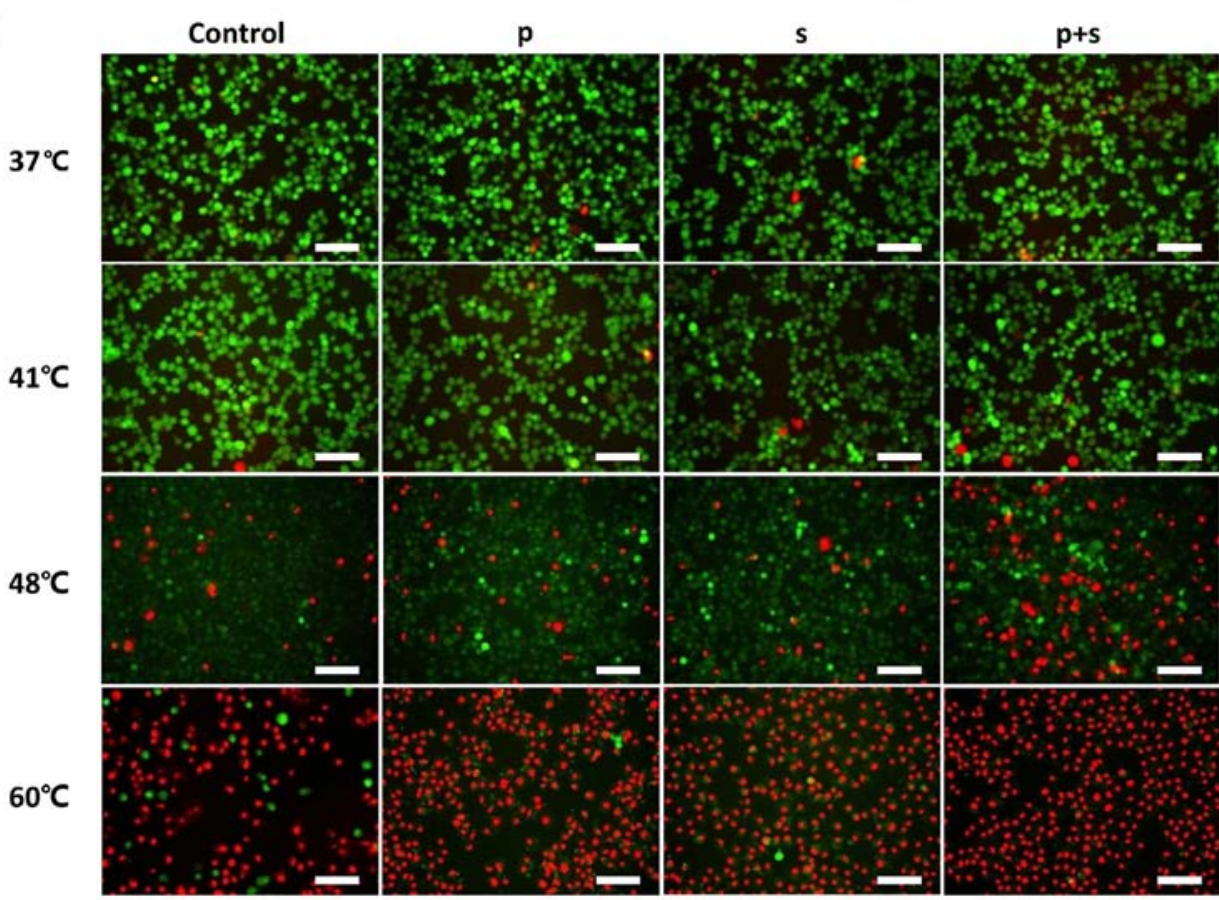

Figure 3. Fluorescent image of microwave ablation combined with inhibitors at the optimal ablation temperature. (A) Time-temperature curve under 15 W microwave ablation $(\mathrm{n}=3)$. (B) Effect of microwave ablation combined with inhibitors on the viability of tumour cells, compared with the $37^{\circ} \mathrm{C}$ control group ( $\mathrm{n}=3)$. (C) Live VX2 cells stained with Calcein-AM are green and the dead cells are red; scale bar $=100 \mu \mathrm{m}$. ${ }^{*} \mathrm{P}<0.05{ }^{* * *} \mathrm{P}<0.01 \mathrm{vs.} 37^{\circ} \mathrm{C}$ control group. M, microwave; p, PF-04929113; s, SB-525334.

5 min. After rinsing with tap water for $10 \mathrm{~min}$, they were counterstained with haematoxylin for $2 \mathrm{~min}$ at room temperature and differentiated with hydrochloric acid alcohol. All samples were observed under a fluorescence microscope (magnification, x400; BX51; Olympus Corporation). Image-Pro Plus 6.0 image analysis software (Media Cybernetics, Inc.) was used to analyse the integrated optical density (IOD) value of each image.

Statistical analysis. Statistical analysis was performed using SPSS version 23.0 (IBM Corp.). Data are expressed as the mean \pm SD. Statistical comparisons among multiple treatment groups were measured using one-way ANOVA followed by a post-hoc multiple comparison Dunnett's test.

\section{Results}

Cell survival rate of VX2 cells decreases with microwave treatment combined with inhibitors. In the physiotherapy mode of the microwave therapy device, the temperature and time are linearly related when the power is $15 \mathrm{~W}$ (Fig. 3A). The times required to reach the temperatures of 41,48 and $60^{\circ} \mathrm{C}$ were 15,30 and $60 \mathrm{sec}$, respectively. MTT results showed that the survival rate of VX2 cells decreased with increasing temperature in all groups. The addition of inhibitors at 37 and $41^{\circ} \mathrm{C}$ had no significant effect on the survival rate of VX2 cells compared with the $37^{\circ} \mathrm{C}$ control group. When the temperature was $48^{\circ} \mathrm{C}$, the survival rate of VX2 cells was $82.75 \%$ in the control group, $64.81 \%$ in the p group, $63.18 \%$ in the $\mathrm{s}$ group and $37.18 \%$ in the $\mathrm{p}+\mathrm{s}$ group (Fig. 3B). The cell survival rate of the $48^{\circ} \mathrm{C} \mathrm{M}+\mathrm{p}+\mathrm{s}$ group was significantly lower compared with the $48^{\circ} \mathrm{C}$ control, $\mathrm{M}, \mathrm{M}+\mathrm{s}$ and $\mathrm{M}+\mathrm{p}$ groups $(\mathrm{P}<0.05)$. The cell survival rate in the $60^{\circ} \mathrm{C}$ group was significantly lower compared with the other temperature groups $(\mathrm{P}<0.05$; Fig. 3B).

As shown in Fig. 3C, most of the VX2 cells were viable at 37 and $41^{\circ} \mathrm{C}$. A small number of dead cells was observed in the groups treated with inhibitors. When the temperature reached $48^{\circ} \mathrm{C}$, an increased number of dead cells was found and the number of dead cells in the $\mathrm{p}+\mathrm{s}$ group was greater than in the control group. At $60^{\circ} \mathrm{C}$, only a few live cells were observed in the control group. These results were in accordance with the MTT results. 
A
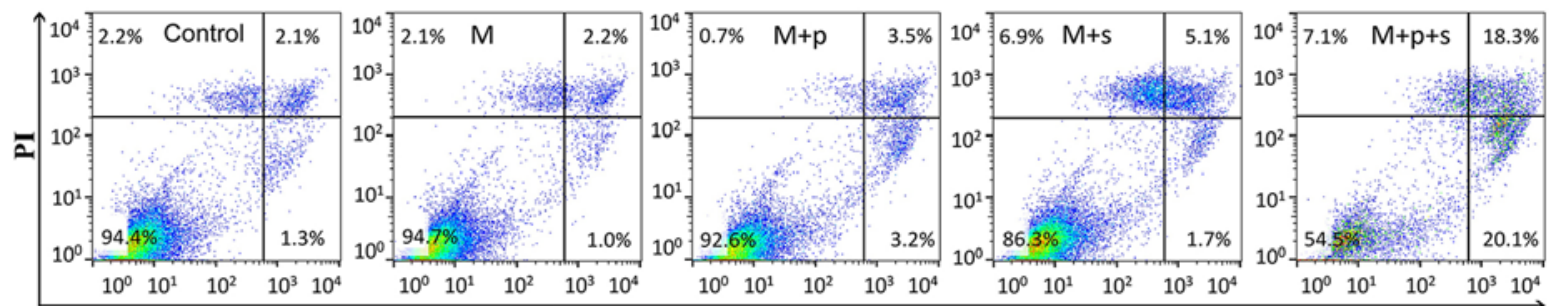

B

B Control

M

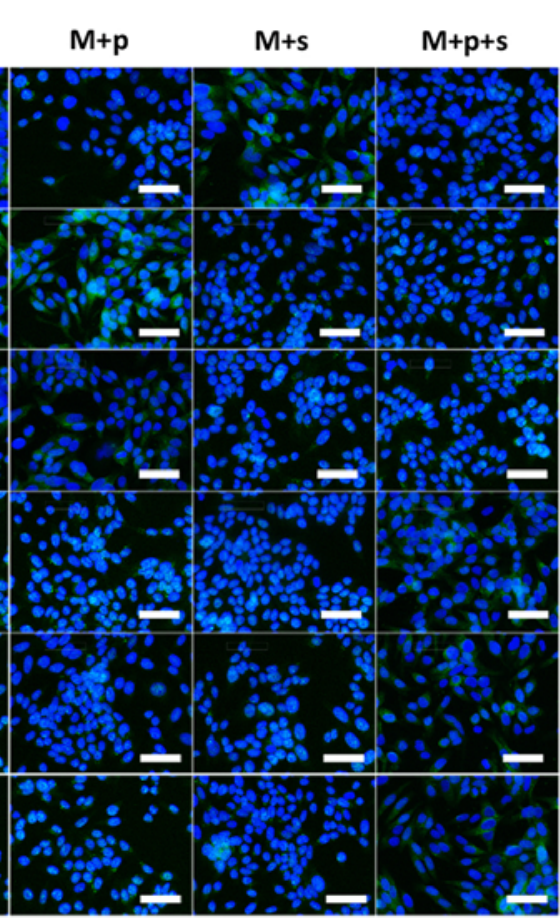

C
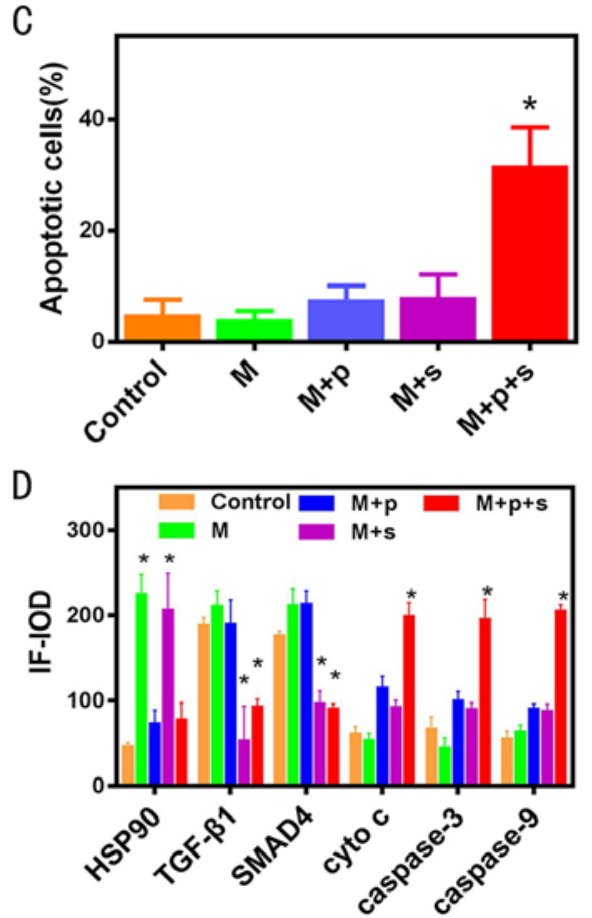

Figure 4. Microwave to $48^{\circ} \mathrm{C}$ combined with HSP90 and TGF- $\beta 1$ inhibitors promotes the apoptosis of VX2 cells. (A) Proportion of apoptosis after microwave ablation combined with inhibitors in VX2 cells. (B) Apoptosis-related signalling proteins detected by immunofluorescence staining; blue, DAPI; green, Alexa Fluor showing positively expressed protein; scale bar $=50 \mu \mathrm{m}$. (C) Corresponding statistical results of flow cytometry ( $\mathrm{n}=3$ ). (D) Corresponding statistical results of cellular immunofluorescence images $(\mathrm{n}=3)$. ${ }^{*} \mathrm{P}<0.05$ vs. control group. cyto $c$, cytochrome $c$; HSP90, heat shock protein 90 ; IF-IOD, immunofluorescence-integrated optical density; M, microwave; p, PF-04929113; PI, propidium iodide; s, SB-525334; TGF- $\beta 1$, transforming growth factor- $\beta 1$.

Treatment with inhibitors followed by microwave ablation increases cell apoptotic rate. As shown in Fig. 4A, when cells were subjected to microwaving at $48^{\circ} \mathrm{C}$, the apoptotic rate was $3.4 \%$ in the control group, $3.2 \%$ in the $\mathrm{M}$ group, $6.7 \%$ in the $\mathrm{M}+\mathrm{p}$ group, $6.8 \%$ in the $\mathrm{M}+\mathrm{s}$ group and $38.4 \%$ in the $\mathrm{M}+\mathrm{p}+\mathrm{s}$ group. The quantitative data revealed that the $\mathrm{M}+\mathrm{p}+\mathrm{s}$ group had a significantly higher apoptotic rate compared with the control group (Fig. 4C).

As determined by immunofluorescence, HSP 90 , TGF- $\beta 1$ and SMAD4 expression was increased in the $M$ group, whereas cyto $c$, caspase-3 and caspase-9 expression was not altered in the $\mathrm{M}$ group when compared with the control group (Fig. 4B and D). In the M+s group, the expression of apoptotic downstream signalling pathway-related proteins were similar to that of the $\mathrm{M}$ group. The expression of cyto $c$, caspase- 3 and caspase- 9 was significantly increased in the $\mathrm{M}+\mathrm{p}+\mathrm{s}$ group compared with the $\mathrm{M}$ group (Fig. 4B and D), indicating that the TGF- $\beta 1$ inhibitor could promote the signalling pathway of apoptosis. In addition, the IOD values of HSP90 in the M and M+s groups were significantly increased, whereas those in the $\mathrm{M}+\mathrm{p}$ and $\mathrm{M}+\mathrm{p}+\mathrm{s}$ groups were similar to those in the control group. The IOD values of TGF- $\beta 1$ in the $\mathrm{M}+\mathrm{p}$ and $\mathrm{M}+\mathrm{p}+\mathrm{s}$ groups were significantly decreased when compared with the control group (Fig. 4B and D).

Western blotting analysis. Fig. 5A and B shows the expression levels of proteins associated with the HSP90 and TGF- $\beta 1 / S M A D 4$ signalling pathways. In the $\mathrm{M}+\mathrm{p}+\mathrm{s}$ groups, the expression levels of TGF- $\beta 1$ and SMAD4 were significantly decreased. HSP90 in the VX2 cells was significantly upregulated by microwaving to $48^{\circ} \mathrm{C}$, whereas the expression levels of the other proteins in the $\mathrm{M}$ group were similar to that of the control group. When combined with the HSP90 inhibitor (M+p group), the expression of HSP90 in VX2 cells was reduced. The expression levels of cyto $c$, caspase- 3 and caspase- 9 were markedly increased in the $\mathrm{M}+\mathrm{p}+\mathrm{s}$ group when compared with the control group.

Microwave ablation has no significant effects on the survival rate of R-BMSC cells. As shown in Fig. 5C there was no significant difference in the survival rate of the R-BMSCs after microwave treatment at $48^{\circ} \mathrm{C}$ compared with the control group, even when inhibitors were used in combination. 
A

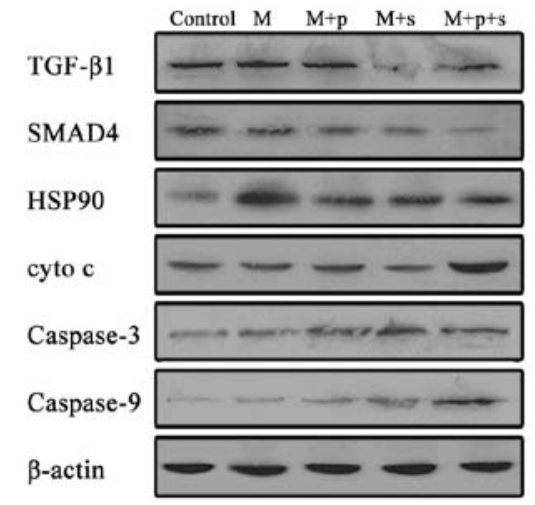

B

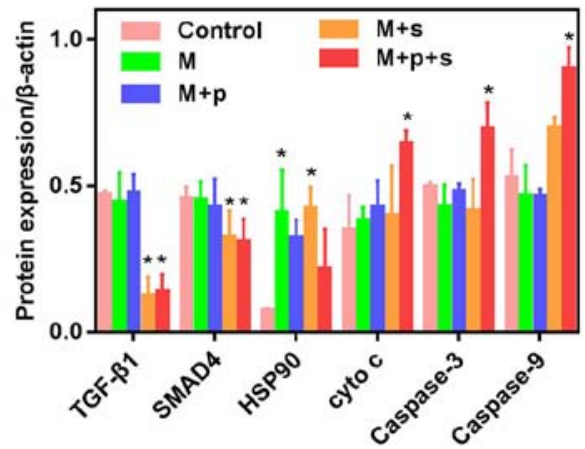

M

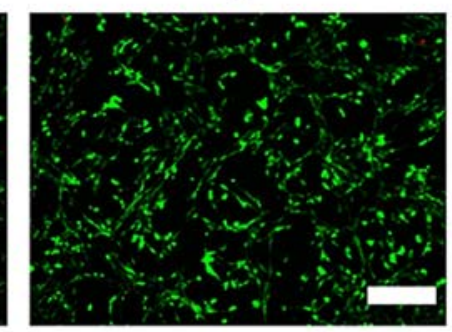

$\mathrm{M}+\mathrm{p}+\mathrm{s}$
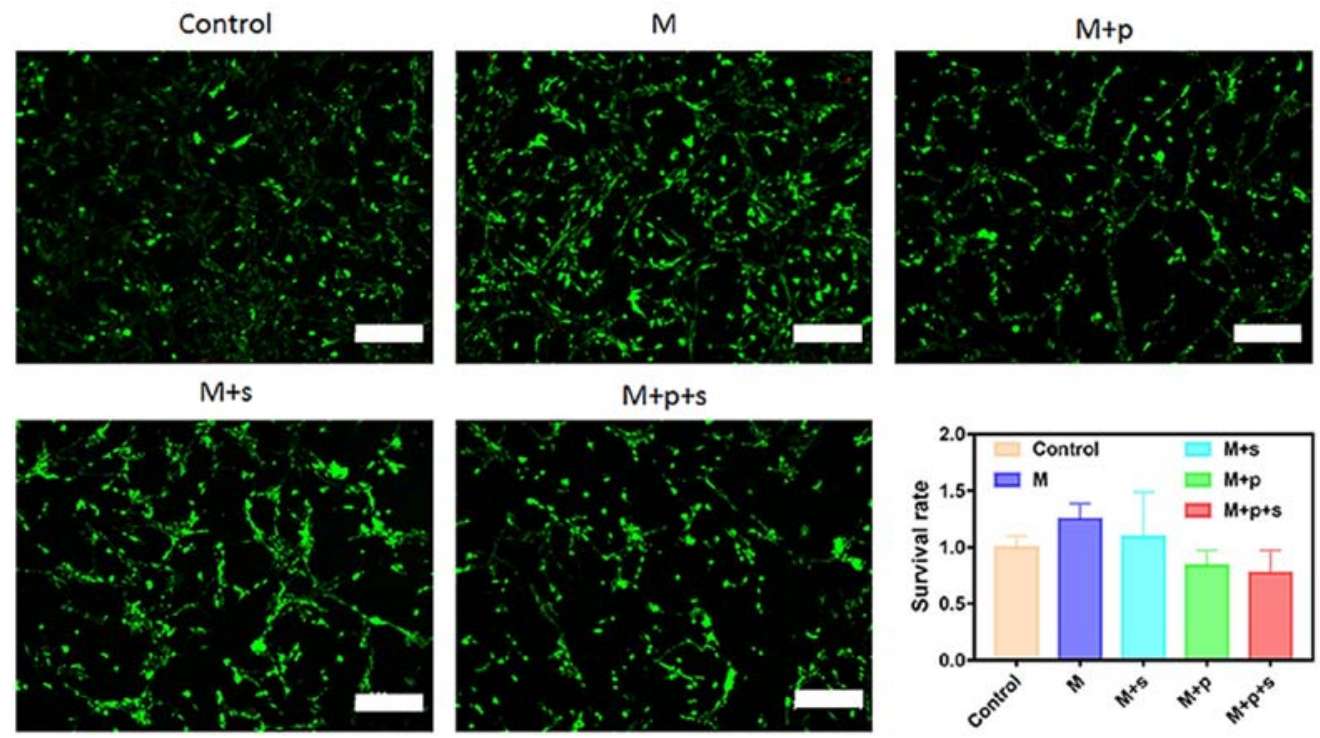

Figure 5. Microwaving to $48^{\circ} \mathrm{C}$ combined with HSP 90 and TGF- $\beta 1$ inhibitors promotes the apoptosis of VX2 cells. (A) Expression of typical proteins involved in the HSP90 and TGF-31/SMAD4 signalling pathway in VX2 cells after microwave ablation combined with inhibitors. (B) Corresponding statistical results of western blotting $(\mathrm{n}=3)$. (C) Cell staining and MTT assay of the VX2 cells after microwave ablation combined with inhibitors in the R-BMSC cells; live R-BMSC cells stained with Calcein-AM are green and dead cells are red; scale bar $=100 \mu \mathrm{m}$. ${ }^{*} \mathrm{P}<0.05$ vs. control group. cyto $c$, cytochrome $c$; HSP90, heat shock protein 90; M, microwave; $\mathrm{p}$, PF-04929113; s, SB-525334; TGF- $\beta 1$, transforming growth factor- $\beta 1$.

Changes in tumour volume and body weight. The weight of the rabbits in each group increased over 0-21 days, the rabbits were $\sim 1.5 \mathrm{~kg}$ before surgery and $\sim 2.0 \mathrm{~kg} 21$ post-surgery (Fig. 6A). However, there were no significant differences in body weight among the groups at each time point. No rabbit was found to have multiple tumours. As shown in Fig. 6B, there was an increase in tumour volume in all groups over the 0-21 days after microwave ablation. The $\mathrm{M}+\mathrm{p}+\mathrm{s}$ group had the smallest volume at 21 days post-surgery, the volume was $\sim 58.05 \%$ of the control group and was lower than that of the other groups. In addition, there were a large number of tumour cells observed in the control group, which decreased in the groups subjected to microwave treatment; the $\mathrm{M}+\mathrm{p}+\mathrm{s}$ group had the lowest number of tumour cells among these groups (Fig. 6E).

Immunohistochemistry. As shown in Fig. 6C and F, HSP90 expression in VX2 tumour tissue was significantly increased after microwaving at $48^{\circ} \mathrm{C}$, whereas the expression levels of the other proteins were similar to that of the control group. When combined with the HSP90 inhibitor (M+p group), the expression of HSP90 in VX2 tumour tissues decreased to close to that of the control group. When combined with the TGF- $\beta 1$ inhibitor ( $\mathrm{M}+\mathrm{s}$ and $\mathrm{M}+\mathrm{p}+\mathrm{s}$ groups), the expression levels of TGF- $\beta 1$ and SMAD4 were significantly decreased compared with the control group. The expression of cyto $c$, caspase-3 and caspase -9 markedly increased in the $\mathrm{M}+\mathrm{p}+\mathrm{s}$ group when compared with the control group.

\section{Discussion}

The use of microwave therapy on tumours is associated with the risk of causing thermal damage to the surrounding normal tissues due to the high temperatures generated by the microwave thermal effect. A previous study reported the effect of hyperthermic temperatures on cells, the findings were as follows: Between 37 and $41^{\circ} \mathrm{C}$, cells maintained a dynamic balance; between 41 and $48^{\circ} \mathrm{C}$ for $>60$ min triggered irreversible damage to the cells; between 48 and $60^{\circ} \mathrm{C}$ for only $4-6$ min led to irreversible damage to proteins, DNA and cells; $>60^{\circ} \mathrm{C}$ caused the protein to immediately coagulate, and the cells were immediately and irreversibly damaged (18).

Based on the aforementioned studies, four microwave ablation temperatures $\left(37,41,48\right.$ and $\left.60^{\circ} \mathrm{C}\right)$ were set in this experiment, and the effect of microwave ablation combined 
A

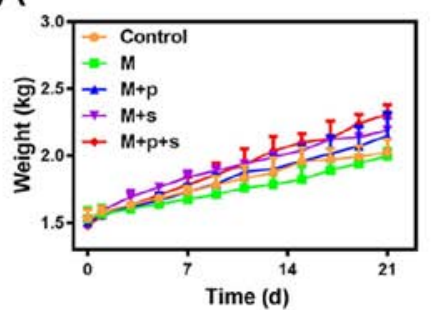

B

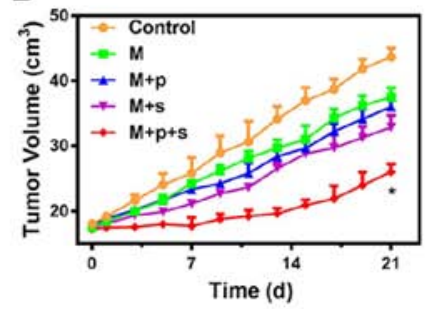

C

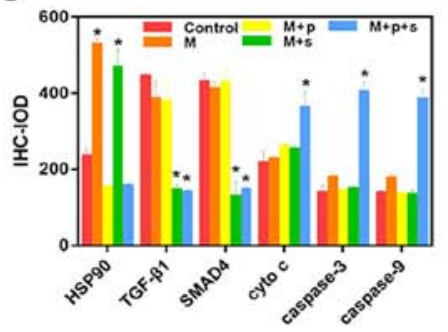

D

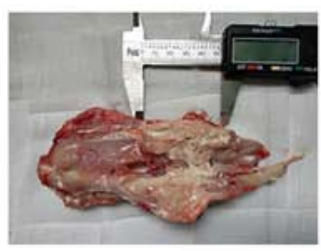

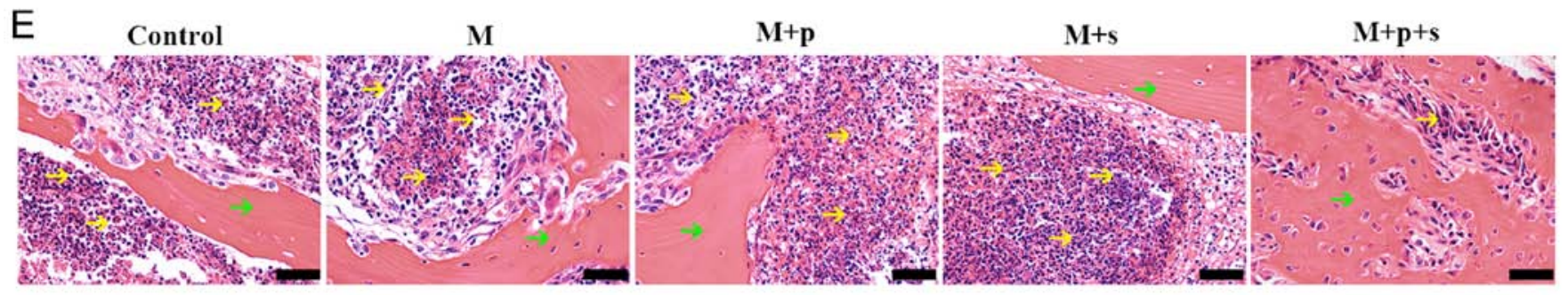

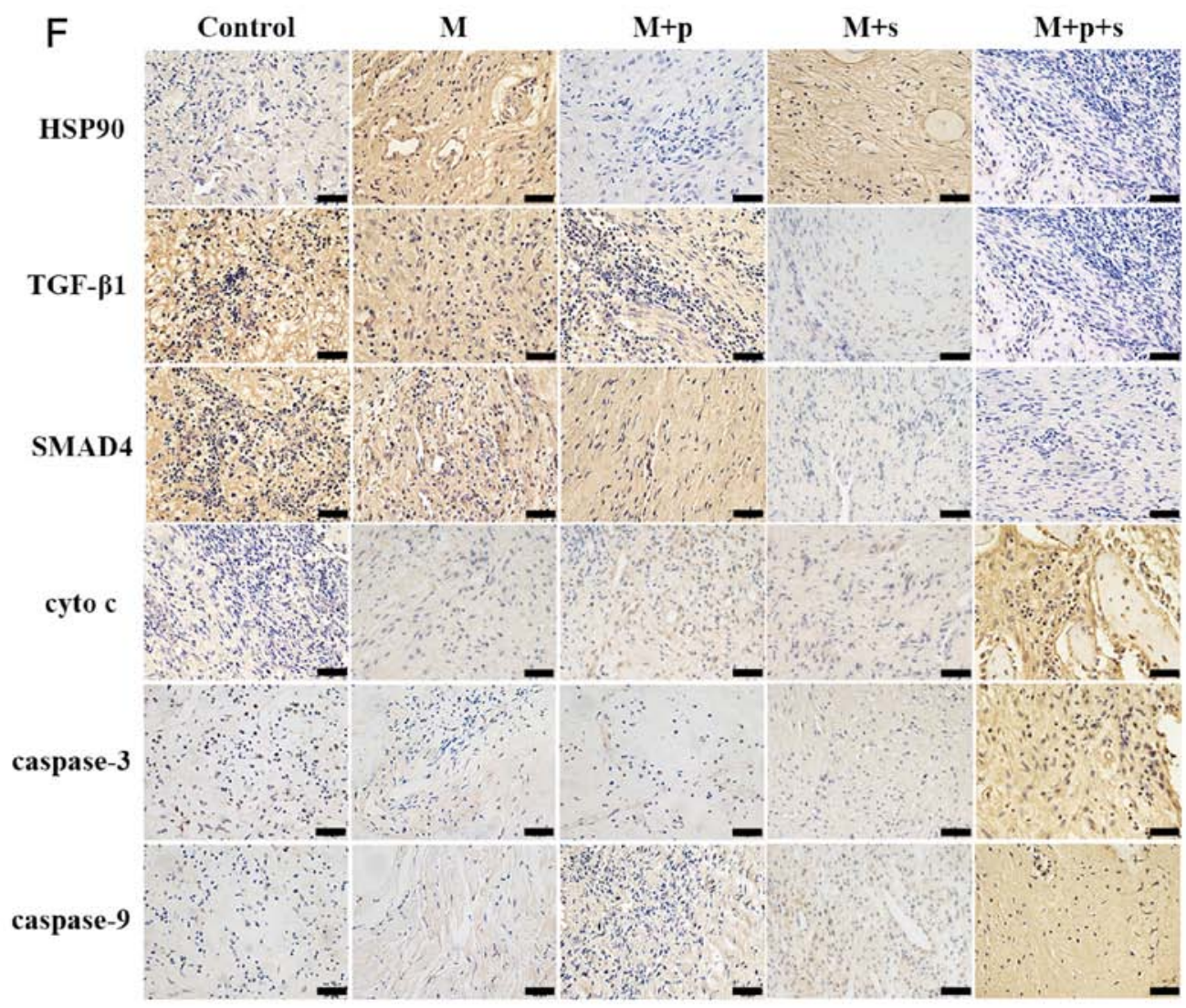

Figure 6. In vivo experiment results. (A) Changes in body weight of the New Zealand rabbits; data are expressed as the mean \pm SD ( $=6$ ). (B) Changes in tumour volume after osteosarcoma treatment with mild microwave ablation combined with TGF- $\beta 1$ and HSP90 inhibitors. (C) Corresponding statistical results of immunohistochemical images $(n=6)$. (D) Representative tumour tissue. (E) H\&E staining was used to detect the changes of tumour tissue after tumour treatment with microwave ablation combined with inhibitors; yellow arrows indicate tumour tissue and green arrows indicate bone tissue; scale bar $=50 \mu \mathrm{m}$. (F) Immunohistochemical detection of the signalling pathway-related proteins after mild microwave ablation combined with inhibitors for the treatment of osteosarcoma; scale bar $=50 \mu \mathrm{m}$. * $\mathrm{P}<0.05$ vs. control group. cyto $c$, cytochrome $c$; HSP90, heat shock protein 90 ; IHC-IOD, immunohistochemistry-integrated optical density; M, microwave; p, PF-04929113; s, SB-525334; TGF- $\beta 1$, transforming growth factor- $\beta 1$.

with the TGF- $\beta 1$ and HSP90 inhibitors on the survival rate of osteosarcoma tumours was investigated. The present study revealed that the survival rate of VX2 cells after microwaving to $48^{\circ} \mathrm{C}$ combined with TGF- $\beta 1$ and HSP90 inhibitors, the rate of apoptosis was significantly higher than the microwave or inhibitor treatment groups alone. The results of the in vivo experiments also demonstrated the same synergistic tumour treatment effect, without any systemic effect on the experimental rabbits, as during the experiment, there was no significant difference in the weight of the rabbits in each group.

The effect of this combination therapy could be attributed to the combination of two inhibitors blocking the synergistic activity of TGF- $\beta 1$ and HSP90. Although HSP90 is essential for the survival of healthy cells, cancer cells have been shown to 
be more dependent on HSP90, and therefore require increased active HSP90 compared with normal tissues (20), which may provide a novel target for tumour therapy. In the present study, live/dead staining and MTT assays were used to verify that microwave ablation at $48^{\circ} \mathrm{C}$ combined with inhibitors had no significant effect on the survival rate of R-BMSCs. This may be because normal cells are less sensitive to thermal stimulation than tumour cells (21). A previous study reported that the anti-tumour effect of the HSP90 inhibitor may be mediated by a significant decrease in TGF- $\beta 1$ at the post-translational level rather than the transcript level, followed by a decrease in SMAD2/3 (22). Moreover, TGF- $\beta 1$ and HSP90 can bind to the same receptor (23), and previous studies have investigated their synergistic effects on tumour cell adhesion, migration and immunoglobulins $(24,25)$. TGF- $\beta 1$ has no effect on the adhesion and migration levels of tumour cells, but the addition of HSP90 can increase the adhesion of metastatic tumour cells without affecting the migration of primary tumour cells $(26,27)$.

In the present study, the results of cellular immunofluorescence and Immunohistochemistry demonstrated that SB-525334 blocked the expression of TGF- $\beta 1$ and SMAD4, and PF-04929113 blocked the expression of HSP90 but significantly increased the expression of apoptosis-related proteins cyto $c$, caspase-3 and caspase-9. In Fig. 4D and B, HSP90 in the $\mathrm{M}+\mathrm{p}$ group decreased, but cyto $\mathrm{c}$ and caspases were also affected by other signaling pathways, thus there was no significant decrease overall. When an injury signal is transmitted to the mitochondria, mitochondrial outer membrane permeabilization leads to the release of cyto $c$ into the cytoplasm (28), where it binds and activates apoptotic peptidase activating factor 1 (APAF1) (29). APAF1 has a caspase activation and recruitment binding domain (CARD), which is homologous to the initiating apoptotic protease caspase-9, so that activated APAF1 can aggregate and activate caspase- 9 in a CARD-CARD manner, forming a cytochrome apoptotic body composed of cyto $c$, APAF1 and caspase-9, which activates caspase-3 and ultimately induces apoptosis (30).

In another signalling pathway associated with tumour proliferation/apoptosis, TGF- $\beta 1$ phosphorylates and activates TGF- $\beta 1$ type receptors (31). Phosphorylation of receptor-specific SMAD2/3 allows them to oligomerize with the common mediator SMAD4, thereby mediating the proliferation of tumour cells (32). Since TGF- $\beta 1$ and HSP90 are able to bind to the same receptors, HSP90 inhibitors can target TGF- $\beta 1$ signalling at the receptor level (23). HSP90 inhibitors can induce caspase activation by proteolysis (33). Caspase activation is mainly carried out by hydrolysis (34), and thus an immunoblot analysis was performed using an anti-lytic caspase-3/8/9 antibody. It was found that the caspase- 9 content of the $\mathrm{M}+\mathrm{p}+\mathrm{s}$ group cells was significantly higher than that of untreated cells (33). The cleaved form of caspase- 3 was detected in untreated cells, and the caspase- 3 content of the $\mathrm{M}+\mathrm{p}+\mathrm{s}$ group cells was significantly increased compared with untreated cells (33).

When tumour cells are damaged, hypoxia triggers an increase in mitochondrial membrane permeability and cyto $c$ translocates from the mitochondrial matrix to the cytoplasmic matrix (35). The resulting apoptotic body, a complex composed of cyto $c$, APAF1 and caspase-9, then activates the apoptosis-executing caspase-3 to induce apoptosis (36). These reports are consistent with the results of the present study, which suggested that the combination treatment activated tumour cell apoptosis by activating the mitochondrial apoptotic pathway. The immunohistochemical results also revealed that the expression of cyto $c$, caspase- 3 and caspase- 9 were enhanced when microwave ablation was combined with TGF- $\beta 1$ and HSP90 inhibitors, which promoted osteosarcoma apoptosis. A previous study reported that the HSP90 inhibitor 17-DMAG could enhance the apoptotic effect of hyperthermic conditions on melanoma cells via melanoma-induced apoptosis (37), which differs from the inhibitor used of the present study. HSP90 can also inhibit exogenous apoptotic signalling pathways (38); its related anti-tumor effects require further study.

In summary, this study investigated the use of microwaving to $48^{\circ} \mathrm{C}$ combined with HSP90 and TGF- $\beta 1$ inhibitors. It was demonstrated that this combination could decrease cell survival rate and promote apoptosis in osteosarcoma tumours, providing a novel strategy for osteosarcoma treatment by microwave ablation while also offering a solution for the protection of surrounding normal tissues.

\section{Acknowledgements}

Not applicable.

\section{Funding}

The present study was supported by the Science and Technology Planning Project of Guangdong Province (grant nos. 2017B030314139 and 2012B031500014) and the Natural Science Foundation of Guangdong Province (grant no. 2015A030312004).

\section{Availability of data and materials}

The datasets used and/or analyzed during the present study are available from the corresponding author on reasonable request.

\section{Authors' contributions}

QY, YZ and LC conceived and designed the study. LC, MW, ZL, MY, SC, WW and BL performed the experiments and collected the data. LC, WW and MW were major contributors in drafting and revising the manuscript. All authors reviewed and approved the final manuscript.

\section{Ethics approval and consent to participate}

All animal studies were approved by the Institutional Animal Care and Use Committee of Guangzhou General Hospital of Guangzhou Military Command of PLA.

\section{Patient consent for publication}

Not applicable.

\section{Competing interests}

The authors declare that they have no competing interests. 


\section{References}

1. Omer N, Le Deley MC, Piperno-Neumann S, Marec-Berard P, Italiano A, Corradini N, Bellera C, Brugieres L and Gaspar N: Phase-II trials in osteosarcoma recurrences: A systematic review of past experience. Eur J Cancer 75: 98-108, 2017.

2. Miller BJ, Cram P, Lynch CF and Buckwalter JA: Risk factors for metastatic disease at presentation with osteosarcoma: An analysis of the SEER database. J Bone Joint Surg Am 95: e89, 2013.

3. Nomura M, Rainusso N, Lee YC, Dawson B, Coarfa C, Han R, Larson JL, Shuck R, Kurenbekova L and Yustein JT: Tegavivint and the $\beta$-catenin/ALDH axis in Chemotherapy-resistant and metastatic osteosarcoma. J Natl Cancer Inst 111: 1216-1227, 2019

4. Li J, Guo Z, Wang Z, Fan $\mathrm{H}$ and Fu J: Does microwave ablation of the tumor edge allow for joint-sparing surgery in patients with osteosarcoma of the proximal Tibia? Clin Orthop Relat Res 473: 3204-3211, 2015

5. Ogura Y, Naito H, Tsurukawa T, Ichinoseki-Sekine N, Saga N, Sugiura $\mathrm{T}$ and Katamoto S: Microwave hyperthermia treatment increases heat shock proteins in human skeletal muscle. Br J Sports Med 41: 453-455, 2007.

6. Moran LT, Mayer MP and Rüdiger SGD: The Hsp70-Hsp90 chaperone cascade in protein folding. Trends Cell Biol 29: 164-177, 2019

7. Lauwers E, Wang YC, Gallardo R, Van der Kant R, Michiels E, Swerts J, Baatsen P, Zaiter SS, McAlpine SR, Gounko NV, et al: Hsp90 mediates membrane deformation and exosome release. Mol Cell 71: 689-702.e9, 2018.

8. Chang DJ, An H, Kim KS, Kim HH, Jung J, Lee JM, Kim NJ, Han YT, Yun H, Lee S, et al: Design, synthesis, and biological evaluation of novel deguelin-based heat shock protein 90 (HSP90) inhibitors targeting proliferation and angiogenesis. J Med Chem 55: 10863-10884, 2012.

9. Pezzulo AA, Tudas RA, Stewart CG, Buonfiglio L, Lindsay BD, Taft PJ, Gansemer ND and Zabner J: HSP90 inhibitor geldanamycin reverts IL-13- and IL-17-induced airway goblet cell metaplasia. J Clin Invest 129: 744-758, 2019.

10. Neckers L, Kern A and Tsutsumi S: Hsp90 inhibitors disrupt mitochondrial homeostasis in cancer cells. Chem Biol 14: 1204-1206, 2007.

11. Maris P, Blomme A, Palacios AP, Costanza B, Bellahcène A, Bianchi E, Gofflot S, Drion P, Trombino GE, Di Valentin E, et al: Asporin is a fibroblast-derived TGF- $\beta 1$ inhibitor and a tumor suppressor associated with good prognosis in breast cancer. PLoS Med 12: e1001871,2015

12. Xu XF, Liu F, Xin JQ, Fan JW, Wu N, Zhu LJ, Duan LF, Li YY and Zhang H: Respective roles of the mitogen-activated protein kinase (MAPK) family members in pancreatic stellate cell activation induced by transforming growth factor-betal (TGF- $\beta 1$ ). Biochem Biophys Res Commun 501: 365-373, 2018.

13. Magnussen SN, Hadler-Olsen E, Costea DE, Berg E, Jacobsen CC, Mortensen B, Salo T, Martinez-Zubiaurre I, Winberg JO, Uhlin-Hansen L and Svineng G: Cleavage of the urokinase receptor (UPAR) on oral cancer cells: Regulation by transforming growth factor- $\beta 1$ (TGF- $\beta 1$ ) and potential effects on migration and invasion. BMC Cancer 17: 350, 2017.

14. Chen CA, Chang JM, Chang EE, Chen HC and Yang YL: Crosstalk between transforming growth factor- $\beta 1$ and endoplasmic reticulum stress regulates alpha-smooth muscle cell actin expression in podocytes. Life Sci 209: 9-14, 2018.

15. Wang L, Yang J, Ran B, Yang X, Zheng W, Long Y and Jiang X Small Molecular TGF- $\beta 1$-inhibitor-loaded electrospun fibrous scaffolds for preventing hypertrophic scars. ACS Appl Mater Interfaces 9: 32545-32553, 2017.

16. Sibinska Z, Tian X, Korfei M, Kojonazarov B, Kolb JS, Klepetko W Kosanovic D, Wygrecka M, Ghofrani HA, Weissmann N, et al: Amplified canonical transforming growth factor- $\beta$ signalling via heat shock protein 90 in pulmonary fibrosis. Eur Respir J 49: pii: 1501941, 2017.

17. Jaque D, Martinez ML, Del RB, Haro-Gonzalez P, Benayas A, Plaza JL, Martin RE and Garcia SJ: Nanoparticles for photothermal therapies. Nanoscale 6: 9494-9530, 2014

18. Altinsoy A, Dileköz E, Kul O, Ilhan SÖ, Tunccan ÖG, Seven I, Bagriacik EU, Sarioglu Y, Or M and Ercan ZS: A cannabinoid ligand, anandamide, exacerbates endotoxin-induced uveitis in rabbits. J Ocul Pharmacol Ther 27: 545-552, 2011

19. Zhang G, Liu Z, Ding H, Zhou Y, Doan HA, Sin K, Zhu ZJ, Flores R, Wen Y, Gong X, et al: Tumor induces muscle wasting in mice through releasing extracellular Hsp70 and Hsp90. Nat Commun 8: 589, 2017.
20. Hu J, Ding Y, Qian S and Tang X: Simulations of adaptive temperature control with self-focused hyperthermia system for tumor treatment. Ultrasonics 53: 171-177, 2013.

21. Suzuki S and Kulkarni AB: Extracellular heat shock protein HSP90beta secreted by MG63 osteosarcoma cells inhibits activation of latent TGF-beta1. Biochem Biophys Res Commun 398: $525-531,2010$

22. Wrighton $\mathrm{KH}$, Lin $\mathrm{X}$ and Feng XH: Critical regulation of TGFbeta signaling by Hsp90. Proc Natl Acad Sci USA 105: 9244-9249, 2008.

23. de la Mare JA, Jurgens T and Edkins AL: Extracellular Hsp90 and TGF $\beta$ regulate adhesion, migration and anchorage independent growth in a paired colon cancer cell line model. BMC Cancer 17: 202,2017.

24. Lee J, An YS, Kim MR, Kim YA, Lee JK, Hwang CS, Chung E, Park IC and Yi JY: Heat shock protein 90 regulates subcellular localization of smads in Mv1Lu cells. J Cell Biochem 117: 230-238, 2016.

25. Tomcik M, Zerr P, Pitkowski J, Palumbo-Zerr K, Avouac J, Distler O, Becvar R, Senolt L, Schett G and Distler JH: Heat shock protein 90 (Hsp90) inhibition targets canonical TGF- $\beta$ signalling to prevent fibrosis. Ann Rheum Dis 73: 1215-1222, 2014.

26. Snigireva AV, Vrublevskaya VV, Afanasyev VN and Morenkov OS: Cell surface heparan sulfate proteoglycans are involved in the binding of $\mathrm{Hsp} 90 \alpha$ and $\mathrm{Hsp} 90 \beta$ to the cell plasma membrane. Cell Adh Migr 9: 460-468, 2015

27. Liu X, Fu R, Pan Y, Meza-Sosa KF, Zhang Z and Lieberman J: PNPT1 Release from mitochondria during apoptosis triggers decay of Poly(A) RNAs. Cell 174: 187-201.e12, 2018.

28. Saita S, Nolte H, Fiedler KU, Kashkar H, Venne AS, Zahedi RP, Kruger M and Langer T: PARL mediates Smac proteolytic maturation in mitochondria to promote apoptosis. Nat Cell Biol 19: 318-328, 2017.

29. Bononi A, Giorgi C, Patergnani S, Larson D, Verbruggen K, Tanji M, Pellegrini L, Signorato V, Olivetto F, Pastorino S, et al: BAP1 regulates IP3R3-mediated $\mathrm{Ca}^{2+}$ flux to mitochondria suppressing cell transformation. Nature 546: 549-553, 2017.

30. Häger M, Pedersen CC, Larsen MT, Andersen MK, Hother C, Grønbaek K, Jarmer H, Borregaard $\mathrm{N}$ and Cowland JB: MicroRNA-130a-mediated down-regulation of Smad4 contributes to reduced sensitivity to TGF- $\beta 1$ stimulation in granulocytic precursors. Blood 118: 6649-6659, 2011.

31. Lam CK, Zhao W, Cai W, Vafiadaki E, Florea SM, Ren X, Liu Y, Robbins N, Zhang Z, Zhou X, et al: Novel role of HAX-1 in ischemic injury protection involvement of heat shock protein 90. Circ Res 112: 79-89, 2013.

32. Tian C, Gao P, Zheng Y, Yue W, Wang X, Jin H and Chen Q: Redox status of thioredoxin-1 (TRX1) determines the sensitivity of human liver carcinoma cells (HepG2) to arsenic trioxide-induced cell death. Cell Res 18: 458-471, 2008.

33. Milasta S, Dillon CP, Sturm OE, Verbist KC, Brewer TL, Quarato G, Brown SA, Frase S, Janke LJ, Perry SS, et al: Apoptosis-inducing-factor-dependent mitochondrial function is required for T cell but Not B cell function. Immunity 44: 88-102, 2016.

34. Shin MK, Jeong KH, Choi H, Ahn HJ and Lee MH: Heat shock protein 90 inhibitor enhances apoptosis by inhibiting the AKT pathway in thermal-stimulated SK-MEL-2 human melanoma cell line. J Dermatol Sci 90: 357-360, 2018.

35. Tahmasbi V, Ghoreishi $\mathbf{M}$ and Zolfaghari M: Investigation, sensitivity analysis, and multi-objective optimization of effective parameters on temperature and force in robotic drilling cortical bone. Proc Inst Mech Eng H 231: 1012-1024, 2017.

36. Palacios-Rodriguez Y, Garcia-Lainez G, Sancho M, Gortat A, Orzaez M and Perez-Paya E: Polypeptide modulators of caspase recruitment domain (CARD)-CARD-mediated protein-protein interactions. J Biol Chem 286: 44457-44466, 2011.

37. Wagatsuma A, Takayama Y, Hoshino T, Shiozuka M, Yamada S, Matsuda R and Mabuchi K: Pharmacological targeting of HSP90 with 17-AAG induces apoptosis of myogenic cells through activation of the intrinsic pathway. Mol Cell Biochem 445: 45-58, 2018.

38. Ke X, Chen J, Peng L, Zhang W, Yang Y,Liao X, Mo L, Guo R, Feng J, $\mathrm{Hu}$ C, et al: Heat shock protein 90/Akt pathway participates in the cardioprotective effect of exogenous hydrogen sulfide against high glucose-induced injury to H9c2 cells. Int J Mol Med 39: 1001-1010, 2017.

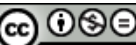

This work is licensed under a Creative Commons Attribution-NonCommercial-NoDerivatives 4.0 International (CC BY-NC-ND 4.0) License. 